\title{
Spatial variability in recruitment of acroporid corals and predatory starfish along the Onna coast, Okinawa, Japan
}

\author{
Masako Nakamura ${ }^{1,6, *}$, Naoki H. Kumagai ${ }^{2}$, Kazuhiko Sakai ${ }^{3}$, Ken Okaji ${ }^{4}$, \\ Kei Ogasawara ${ }^{5}$, Satoshi Mitarai ${ }^{1}$ \\ ${ }^{1}$ Marine Biophysics Unit, Okinawa Institute of Science and Technology, Onna, Okinawa 904-0412, Japan \\ ${ }^{2}$ National Institute for Environmental Studies, Tsukuba, Ibaraki 305-8506, Japan \\ ${ }^{3}$ Sesoko Station, Tropical Biosphere Research Center, University of the Ryukyus, Motobu, Okinawa 905-0227, Japan \\ ${ }^{4}$ Coralquest Inc., Atsugi, Kanagawa 243-0014, Japan \\ ${ }^{5}$ Okinawa Environment Science Center, Urasoe, Okinawa 901-2111, Japan \\ ${ }^{6}$ Present address: School of Marine Science and Technology, Tokai University, Shimizu, Shizuoka 424-8610, Japan
}

\begin{abstract}
We compared spatial variability in recruitment patterns between acroporid corals and the predatory crown-of-thorns starfish Acanthaster planci along the Onna village coast of Okinawa Island, Japan. Our objective was to understand population dynamics of both predator and prey. To quantify recruitment, we established artificial recruitment plates for acroporid corals and conducted quadrat surveys for juvenile A. planci at 7 sites. We also examined distributional patterns of adult populations of both species and observed surface currents during larval dispersal periods using GPS-equipped surface drifters. Acroporid recruits typically arrived in greater numbers at more northern sites. Despite high variability, A. planci recruits displayed similar spatial patterns. Drifter trajectories suggest that these spatial recruitment patterns are probably driven by near-shore currents in the summer. Moreover, current data imply a complicated metapopulation relationship in this region, especially for $A$. planci, new recruits of which may mainly originate outside of the Onna area. Metapopulation dynamics within the study area and among surrounding regions must be explained by the complex surface current circulation, because simpler explanations involving only the Kuroshio Current do not adequately describe the relationship between these populations.
\end{abstract}

KEY WORDS: Coral reefs $\cdot$ Larval dispersal $\cdot$ Prey and predator $\cdot$ Ocean currents $\cdot$ Crown-of-thorns $\cdot$ COTS

\footnotetext{
*Corresponding author: mnakamura@tsc.u-tokai.ac.jp
}
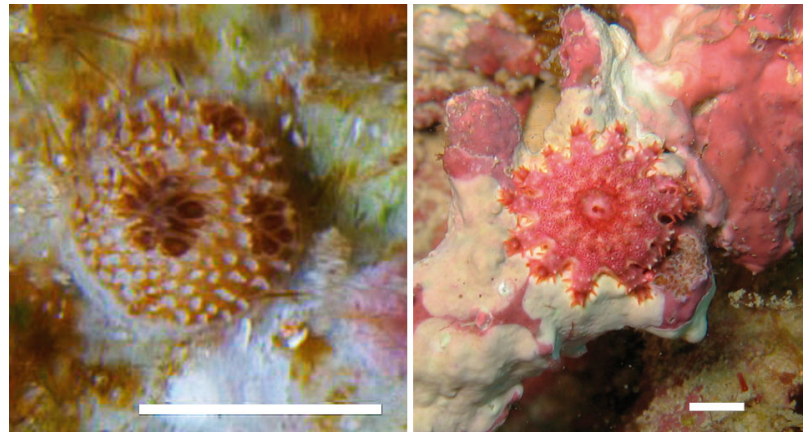

New recruits: an acroporid coral (scale bar $=1 \mathrm{~mm}$ ) and a crown-of-thorns starfish Acanthaster planci (scale bar $=2 \mathrm{~mm}$ ).

Photos: Masako Nakamura and Kei Ogasawara

\section{INTRODUCTION}

Coral cover is declining throughout the IndoPacific region due to a wide variety of natural and anthropogenic disturbances, including storms, sea surface temperature anomalies, diseases, outbreaks of corallivorous starfish, eutrophication, sedimentation, and destructive fishing (Bruno \& Selig 2007). For instance, in the Great Barrier Reef (GBR), approximately half of the coral cover was lost between 1985 and 2012. Predation by the crown-ofthorns starfish Acanthaster planci (L.) was estimated to account for $42 \%$ of coral mortality on the GBR (De'ath et al. 2012). In Okinawa, Japan, coral cover

() The authors 2015. Open Access under Creative Commons by Attribution Licence. Use, distribution and reproduction are unrestricted. Authors and original publication must be credited. 
has also drastically decreased due to outbreaks of A. planci during the 1970s and 1980s (Yamaguchi 1986, Sakai et al. 1988) and a subsequent massbleaching event (Loya et al. 2001). In recent years, some reefs have suffered chronically high densities of A. planci (Nakamura et al. 2014), although extensive damage to corals by $A$. planci has been reported throughout the Indo-Pacific region for more than 50 yr (De'ath et al. 2012).

A. planci is the major coral predator in the IndoPacific (Birkeland \& Lucas 1990). Although it also feeds on coral species belonging to other families (De'ath \& Moran 1998), it strongly prefers acroporid corals, which comprise more than 100 species in this region (Veron 1995). To determine whether coral communities in the Indo-Pacific are sustainable, it is essential to understand processes that structure and maintain populations of both predator and prey.

Larval supply plays a critical role in the dynamics, resilience, and maintenance of communities of benthic marine animals with planktonic propagules, such as corals and A. planci (Underwood \& Fairweather 1989). Dispersal of planktonic larvae is governed by interactions between larval attributes and environmental features (Pineda et al. 2007), and this affects subsequent recruitment. Acroporids and starfish exhibit both similarities and differences in their life-history traits. Acroporids generally fertilize externally and broadcast-spawn (Harrison \& Wallace 1990, Baird et al. 2009), and synchronize spawning within a region to maximize fertilization success. Spawning is generally triggered by a full moon in late spring, mainly during October/November in the GBR (Babcock et al. 1986), and May/June in the Ryukyu Islands (Hayashibara et al. 1993). Acroporid larvae, which are lecithotrophic, reportedly start settling 3 d after spawning (Nishikawa \& Sakai 2005, Suzuki et al. 2011), with most settlement occurring 5 to $8 \mathrm{~d}$ after spawning (Suzuki et al. 2011); however, larvae of some acroporid species remain competent to settle up to $69 \mathrm{~d}$ after spawning in spite of a low survival rate $(<10 \%)$ (Nishikawa \& Sakai 2005). Some can survive for up to $209 \mathrm{~d}$, despite the dramatic decline in survival rate in the first several weeks after spawning, and unknown competency (Graham et al. 2008).

A. planci also has a planktonic larval period. Starfish spawning peaks in December in the GBR (Babcock \& Mundy 1992), and in July along the Ryukyus, when water temperatures exceed $28^{\circ} \mathrm{C}$ (Yokochi \& Ogura 1987, Yasuda et al. 2010). After passing through bipinnaria and brachiolaria larval stages, A. planci larvae are assumed to develop settlement competence approximately $11 \mathrm{~d}$ after spawning, although their planktonic larval duration (PLD) can be as long as 6 wk (Birkeland \& Lucas 1990). In addition, $A$. planci larvae are planktotrophic, and therefore survivorship largely depends on phytoplankton availability (Fabricius et al. 2010). Thus, for the most part, the larval periods of this predator and its prey are non-overlapping. They also have different larval forms and PLDs. Since differences in early life-history traits affect larval dispersal processes (Pineda et al. 2007), coral and starfish larvae may experience different conditions, resulting in different larval dispersal and recruitment patterns. Differential interactions with environmental factors are potentially quite complicated.

In this study, we compared spatial variability in recruitment between acroporid corals and A. planci, examining how differences in life-history traits affect larval dispersal and subsequent recruitment patterns. To comprehend dispersal patterns, it is necessary to determine the distribution patterns of reproductive adults, and to understand surface current movements in target areas. These data may provide insights into mechanisms of population maintenance both for acroporids (which are one of the foundation species of Indo-Pacific coral reef ecosystems) and A. planci.

\section{MATERIALS AND METHODS}

\section{Study site}

Onna village is located in the central west coast of Okinawa Island, Japan (Fig. 1). The coastline is characterized by fringing reefs. Infestations of Acanthaster planci have occurred repeatedly on these reefs (Sakai et al. 1988) and the chronic presence of this starfish is now an important issue for local coral reef management (Nakamura et al. 2014). To quantify recruitment and adult distribution patterns, 7 sites were selected, spanning the entire Onna coast (Sites S1 to S7; Fig. 1).

\section{Coral recruitment survey}

To assess spatio-temporal patterns of coral recruitment along the Onna coast, 5 to 25 sets of artificial recruitment plates were deployed at each site at approximately $5 \mathrm{~m}$ depths, approximately 1 mo before the predicted acroporid spawning periods dur- 

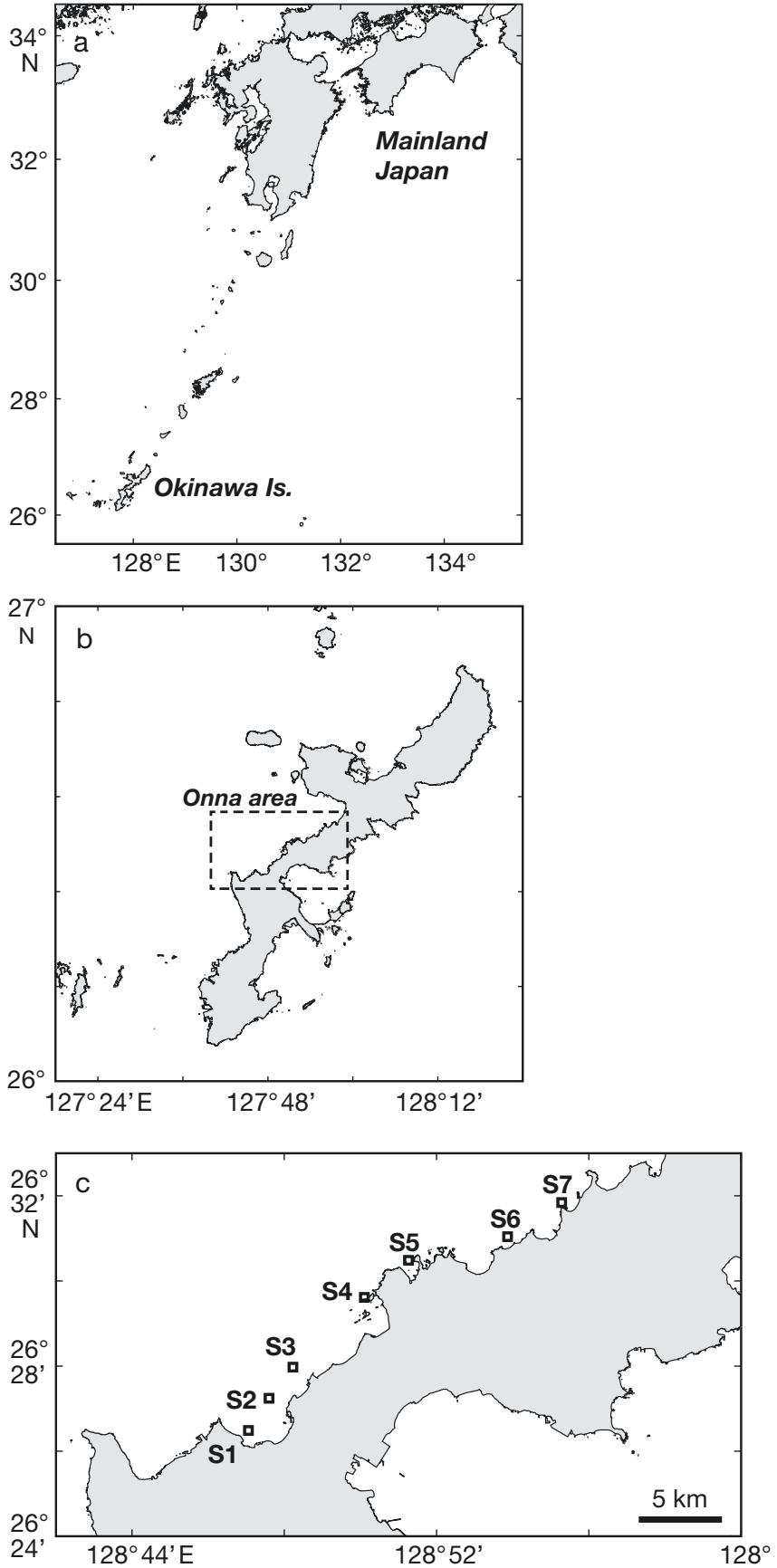

Fig. 1. Study sites, showing (a) Okinawa Island relative to Mainland Japan, (b) Onna area on Okinawa Island, and (c) Sites S1 to S7 along the Onna coast

ing 2011, 2012, and 2013. Around Okinawa, acroporid spawning usually occurs during the full moon in June (Hayashibara et al. 1993). Recruitment plates consisted of a pair of $10 \times 10 \mathrm{~cm}$ panels made of fiberreinforced cement. The 2 panels were fastened one above the other with a $2 \mathrm{~cm}$ gap separating them, so that coral larvae could settle between them. All re- cruitment plates were pre-conditioned in flow-through aquaria for ca. 1 mo prior to deployment in June. Recruitment plates were haphazardly set on substrates, at least $1 \mathrm{~m}$ apart, using underwater epoxy glue. They were retrieved approximately 1 mo after spawning. Retrieved plates were bleached with a chlorine solution for $1 \mathrm{wk}$ to eliminate organic matter and then dried for observation under a stereo microscope. The upper and lower surfaces of the upper panel and the upper surface of the lower panel were observed since the lower surface of the lower panel was used to attach the plates to the substrate. Coral spat on the panels were identified to family (Acroporidae, Pocilloporidae, Poritidae, and others) based upon skeletal morphology (Babcock et al. 2003). The number of spat on the panels was then counted (Hughes et al. 1999).

\section{Recruitment survey of $\boldsymbol{A}$. planci}

To examine spatial variability in recruitment of $A$. planci along the Onna coast, the number of algaeeating juveniles $(<1 \mathrm{~cm}$ diam.) was counted using $50 \times 50 \mathrm{~cm}$ quadrats a few months after settlement. During a pilot study in 2012, algae-eating juveniles were observed at the reef crest in November (M. Nakamura unpubl. data); therefore, surveys of juvenile A. planci were conducted in November and December in 2013. Fifteen quadrats per site were located along the reef crest and upper reef slope (5 to $15 \mathrm{~m}$ depth), where crustose coralline algae (suitable for juvenile $A$. planci) were present.

\section{Surveys of coral communities and of $A$. planci densities}

Corals and A. planci were surveyed at the same sites that were used for coral recruitment surveys. Surveys of coral abundance have been conducted since 2011, and those for A. planci were started in 2013. To estimate coral abundance, between 2 and 5 belt-transects $(20 \times 1 \mathrm{~m})$ were randomly established at each site at a depth of $5 \mathrm{~m}$ in the vicinity of the plates. Four $1 \times 1 \mathrm{~m}$ quadrats were randomly situated along each belt-transect (8 to 20 quadrats per site). Coral assemblages within each quadrat were surveyed and photographed. Each quadrat photo was analyzed by superimposing a 100 -cell grid on it, and each cell was then scored for the presence of coral. When more than $50 \%$ of a given cell was covered with coral, it was scored as positive. By setting the 
threshold at $50 \%$, the number of counts was expected to represent percent cover, which is a timesaving procedure when digitizing coral coverage (Fonseca et al. 2002) and avoids the use of an arcsine transformation to normalize the data. The arcsine transformation is currently not recommended, particularly for percentages over 80 or under $20 \%$ (Ahrens et al. 1990); most coral coverage data in this study were under $20 \%$. Corals were identified to family, but could not be identified below that taxonomic level.

To estimate the abundance of large $A$. planci, the number of $A$. planci at each site was counted in a $5000 \mathrm{~m}^{2}$ area. In general, 2 belt-transects of $125 \times 20 \mathrm{~m}$ were established at each site. At sites where this was not possible, 2 belt-transects of $250 \times 10 \mathrm{~m}$ were employed. Within any given belt-transect, $A$. planci were observed on and beneath corals.

\section{Observation of surface currents}

During the acroporid (June and July) and A. planci (July and August) larval planktonic periods, surface current movement was investigated with Lagrangian drifters (Microstar ${ }^{\mathrm{TM}}$ GPS Drifters; Pacific Gyre), which were specifically designed for coastal ocean current studies. The drifters have drogues $1 \mathrm{~m}$ below the surface, and GPS positioning systems that communicate with the Iridium satellite system. The geographic position of the drifters were sent to a server every $10 \mathrm{~min}$ via this system. Drifters were released from 5 sites (Sites A to E) along the Onna coast (one per site) (see Fig. 7). Drifters were released on 5 occasions during coral and starfish planktonic larval periods (June to August) in 2013 and 2014. In total, 25 drifters were released; however, one of the drifters (released from Site C on 23 July 2013), beached a few hours after release and was therefore excluded from the analysis. Thus there are only 4 lines on the figure for drifter trajectory of 23 July 2013 (see Fig. 7b).

\section{Analysis}

Variations in coral recruitment and adult abundance were examined using generalized linear mixed effects models (GLMMs). Since we counted the number of recruits on the recruitment plates, a Poisson error distribution with log link function was employed for the model. Site (S1 to S7) was considered as a fixed factor with 7 levels. Year was modeled as a normally distributed random intercept term for each site, so it was used only for explaining data variance. For adult acroporid corals, the maximum possible count was 100, so we used a binominal error distribution with logit link function. As the variance of abundance data was overdispersed relative to a Poisson distribution, we used a Poisson-lognormal model to add a dispersion term (Millar 2009).

Since the number of juvenile $A$. planci was low (with many zero counts), we used a zero-inflated Poisson model (ZIP) to analyze juvenile A. planci density. ZIP has 2 parts: a Poisson count model and a logit model for predicting excess zeros. For adults, a generalized linear model (GLM) was applied using a Poisson error distribution with a log link function.

Sites were arranged into groups containing similar densities of corals or $A$. planci using a paired-comparisons information criterion approach (PCIC; Dayton 2003). PCIC is analogous to multiple comparison tests using p-values, however, unlike multiple comparison tests its statistical power does not decrease with the number of comparisons. For the 7 sites, $2^{7-1}$ patterns of grouping subsets were possible. For example, Group $1=(\mathrm{S} 1, \mathrm{~S} 2, \mathrm{~S} 3, \mathrm{~S} 5)$ and Group $2=$ (S4, S6, S7). To identify the optimal subset of the sites, Akaike's information criterion (AIC), $\triangle \mathrm{AIC}$, and Akaike weights $\left(W_{i}\right)$ were used (Burnham \& Anderson 2002). Generally, a $\triangle \mathrm{AIC}$ value $>2$ is taken to be substantial. The $W_{i}$ of a model is used as a measure of the strength of a particular model among all candidate models, and indicates the probability that the model in question is actually the best model.

All analyses were conducted with the free statistical software, R (R Development Core Team 2014). We used 'glmer' in the package 'lme4' to implement GLMM, 'zeroinfl' in package 'pscl' to implement ZIP, and 'dredge' in package 'MuMIn' to rank the subsets.

\section{RESULTS}

\section{Recruitment patterns of acroporid corals and Acanthaster planci along the Onna coast}

Mean acroporid recruitment was higher at more northerly sites along the Onna coast from 2011 to 2013, although differences were less clear in 2012 (Fig. 2, Table 1 \& Table S1 in the Supplement at www.int-res.com/articles/suppl/m540p001_supp.pdf). Over $3 \mathrm{yr}$, each settlement plate $\left(200 \mathrm{~cm}^{2}=0.02 \mathrm{~m}^{2}\right)$ averaged more than 10 coral recruits at Sites S4 to S7 along the Onna coast (Fig. 1). The highest number of recruits was found at Site S5 in 2011 and 2012 (mean 
\pm SD: $33.6 \pm 15.7$ and $17.0 \pm 12.5$ recruits plate $\left.{ }^{-1}\right)$, respectively, and at site S6 in $2013(55.6 \pm 22.1$ recruits plate ${ }^{-1}$ ). The lowest settlement rate consistently occurred at Site S1, ranging from 0 in 2012 to $3.0 \pm$ 2.9 recruits plate ${ }^{-1}$ in 2011.

Mean densities of juvenile Acanthaster planci along the Onna coast in 2013 ranged from 0 to 1.6 ind. $\mathrm{m}^{-2}$ (Fig. 3). The highest density (1.6 \pm 2.5 ind. $\mathrm{m}^{-2}$ ) was observed at Site S6, and more than 1 individual was found at Sites S4 to S6, although standard deviations were high for all sites. However, it was possible to categorize sites into 3 groups in relation to juvenile density, using AIC. Sites within a group were not significantly different in density: Group $1=(\mathrm{S} 1)$, Group $2=(\mathrm{S} 2, \mathrm{~S} 3, \mathrm{~S} 7)$ and Group $3=$ (S4, S5, S6) (see Table S2 in the Supplement).

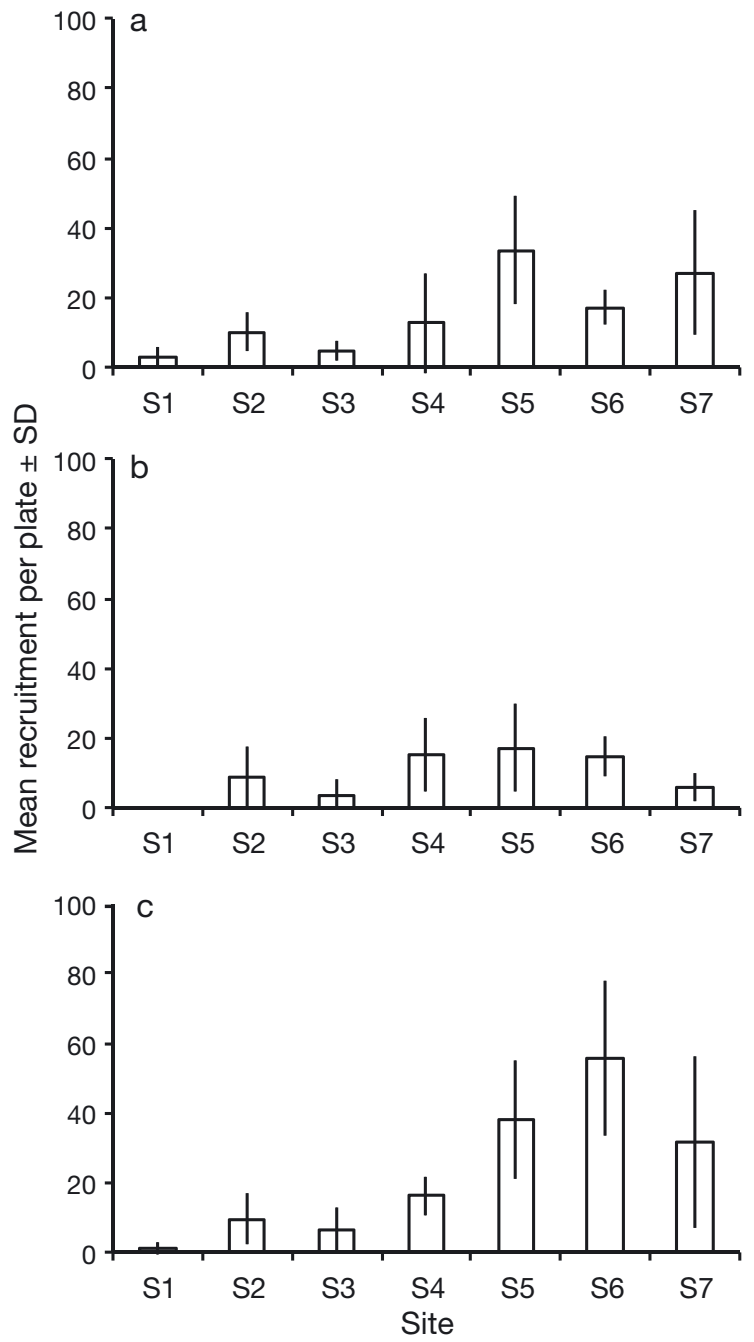

Fig. 2. Mean $( \pm \mathrm{SD})$ recruitment of acroporid corals on settlement plates along the Onna coast (Sites S1 to S7) in (a) 2011, (b) 2012, and (c) 2013
Table 1. Estimates of site effect (as a fixed factor) on acroporid coral recruitment variability

\begin{tabular}{|lllcc|}
\hline & Estimate & \multicolumn{1}{c}{ SE } & z-value & $\operatorname{Pr}(>|z|)$ \\
\hline Intercept & 0.1528 & 0.2998 & 0.51 & 0.61 \\
Site S2 & 2.0433 & 0.246 & 8.307 & $2.00 \times 10^{-16}$ \\
Site S3 & 1.3879 & 0.2724 & 5.096 & $3.47 \times 10^{-7}$ \\
Site S4 & 2.4613 & 0.2524 & 9.754 & $2.00 \times 10^{-16}$ \\
Site S5 & 3.173 & 0.2436 & 13.024 & $2.00 \times 10^{-16}$ \\
Site S6 & 3.1771 & 0.2471 & 12.855 & $2.00 \times 10^{-16}$ \\
Site S7 & 2.8538 & 0.2494 & 11.444 & $2.00 \times 10^{-16}$ \\
\hline
\end{tabular}

\section{Abundance of adult acroporid corals and A. planci along the Onna coast}

Mean $( \pm \mathrm{SD})$ acroporid coral cover was higher at Site S1 $(39.4 \pm 14.9 \%$ in $2011,33.8 \pm 12.0 \%$ in 2012 , $29.25 \pm 16.4 \%$ in 2013) than at other sites (Fig. 4). The difference between $\mathrm{S} 1$ and other sites was significant (Tables 2 \& S3). All other sites had less than 10\% coral cover, with most having less than $1 \%$ cover.

Abundance of adult A. planci also differed among sites (Fig. 5, Tables $3 \&$ S4). More than 10 ind. ha ${ }^{-1}$ were observed at Sites S2, S5, S6, and S7, and Site S6 was above outbreak levels (>15 ind. ha ${ }^{-1}$; Moran \& De'ath 1992), which was the highest abundance we recorded $\left(26 \pm 2.8\right.$ ind. ha $\left.{ }^{-1}\right)$. Fewer than 10 ind. ha ${ }^{-1}$ were observed at Sites S1 and S3, and no starfish were observed at Site S4.

\section{Distribution patterns between recruits and adults along the Onna coast}

Coral cover was higher at the southernmost site, while recruitment was greater in northern sites (Fig. 6a). Distribution patterns of recruits and adult A. planci along the Onna coast did not show any relationship (Fig. 6b).

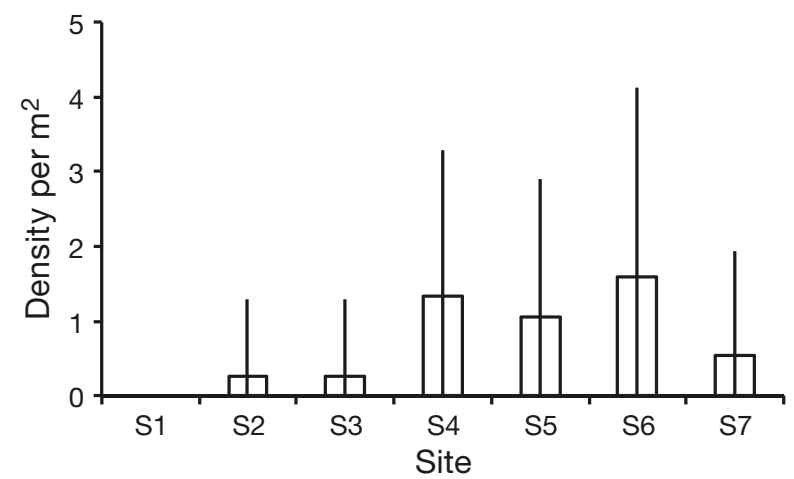

Fig. 3. Mean $( \pm \mathrm{SD})$ density of Acanthaster planci juveniles (ind. $\mathrm{m}^{-2}$ ) along the Onna coast (Sites S1 to S7) in 2013 

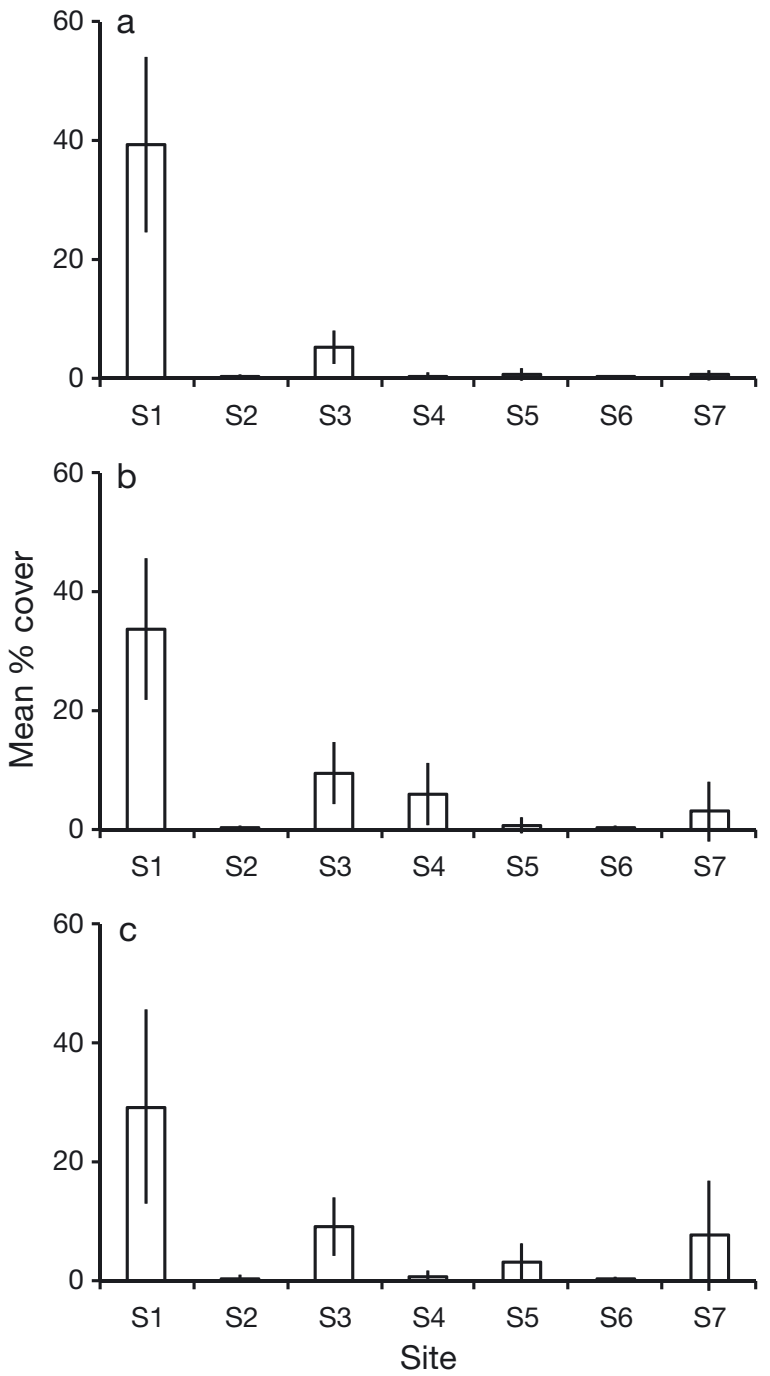

Fig. 4. Mean ( \pm SD) abundance of adult acroporid corals (\% cover $\mathrm{m}^{-2}$ ) along the Onna coast (Sites S1 to S7) in (a) 2011, (b) 2012, and (c) 2013

\section{Surface current movement during planktonic larval periods}

After release, 16 drifters followed the Okinawa coastline northeastward, and then turned northwestward after passing Nago Bay (Fig. 7; see the Supplement for a description of drifter trajectories). This pattern was mainly observed in July and August. Eight other drifters drifted offshore, some from near Site S4. This pattern was mainly observed at the beginning of July 2013 and at the end of June 2014.

Considering the time to beaching as time for competent larvae to reach a reef, 7 drifters beached within $3 \mathrm{~d}$ of their release, 6 did so within $7 \mathrm{~d}, 3$ within $14 \mathrm{~d}$, 1 within $30 \mathrm{~d}$, and the other 7 drifted for more than $30 \mathrm{~d}$ in the open ocean.
Table 2. Estimates of site effect (as a fixed factor) on variability of abundance in acroporid corals

\begin{tabular}{|lcccc|}
\hline & Estimate & SE & $z$-value & $\operatorname{Pr}(>|z|)$ \\
\hline Intercept & -0.7543 & 0.1859 & -4.057 & $4.96 \times 10^{-5}$ \\
Site S2 & -5.7484 & 0.3184 & -18.055 & $2.00 \times 10^{-16}$ \\
Site S3 & -1.8744 & 0.2699 & -6.945 & $3.77 \times 10^{-12}$ \\
Site S4 & -3.6485 & 0.3097 & -11.78 & $2 \times 10^{-16}$ \\
Site S5 & -4.3006 & 0.2564 & -16.771 & $2 \times 10^{-16}$ \\
Site S6 & -5.9089 & 0.4745 & -12.452 & $2.00 \times 10^{-16}$ \\
Site S7 & -3.2981 & 0.3011 & -10.952 & $2 \times 10^{-16}$ \\
\hline
\end{tabular}

Table 3. Estimates of site effect (as a fixed factor) on variability of abundance in the crown-of-thorns starfish

\begin{tabular}{|lrcrc|}
\hline & Estimate & SE & $z$-value & $\operatorname{Pr}(>|z|)$ \\
\hline Intercept & 1.7918 & 0.2887 & 6.207 & $5.41 \times 10^{-10}$ \\
Site S2 & 0.6931 & 0.3536 & 1.961 & $4.99 \times 10^{-2}$ \\
Site S3 & -1.0986 & 0.5774 & -1.903 & 0.0571 \\
Site S4 & -20.0943 & 4042.906 & -0.005 & 0.996 \\
Site S5 & 0.5108 & 0.3651 & 1.399 & 0.1618 \\
Site S6 & 1.4663 & 0.3203 & 4.579 & $4.68 \times 10^{-6}$ \\
Site S7 & 0.8473 & 0.345 & 2.456 & 0.0141 \\
\hline
\end{tabular}

\section{DISCUSSION}

Acroporid corals showed higher recruitment rates at the northern end of the Onna coast than at the southern end. This recruitment pattern varied little over 3 yr. Acanthaster planci recruitment was highly variable and did not show any clear trends, suggesting a patchy juvenile distribution; although their small size and considerable concealment capacity make recruits difficult to locate (Keesing \& Halford 1992, Nakamura et al. 2014), so our conclusions are necessarily tentative. However, there was a slight tendency for higher recruitment at the northern end of the Onna coast. Prior to this study, the recruitment of corals and A. planci had been studied separately.

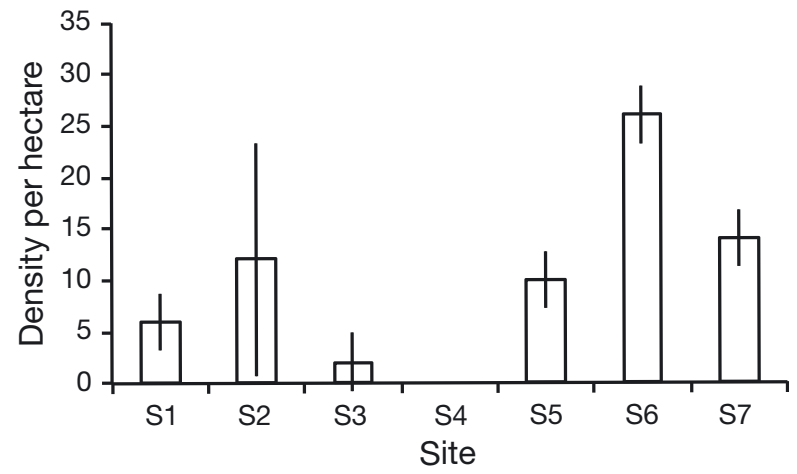

Fig. 5. Mean $( \pm \mathrm{SD})$ density of adult Acanthaster planci (ind. $\mathrm{ha}^{-1}$ ) along the Onna coast (Sites S1 to S7) in 2013 
a) Acroporid corals

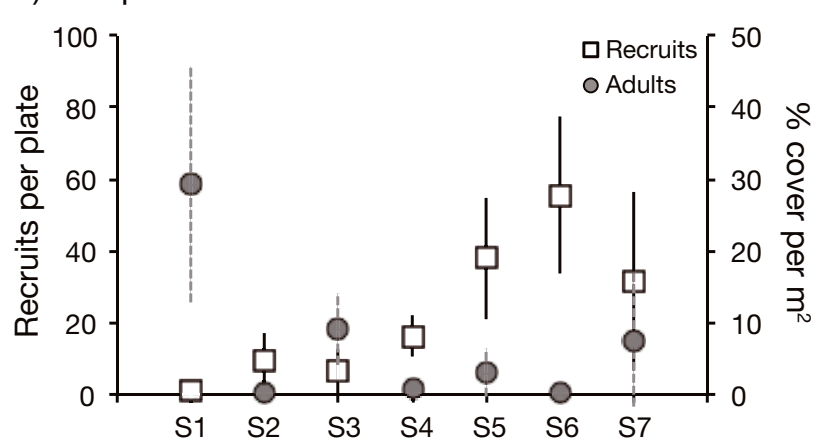

b) Acanthaster planci

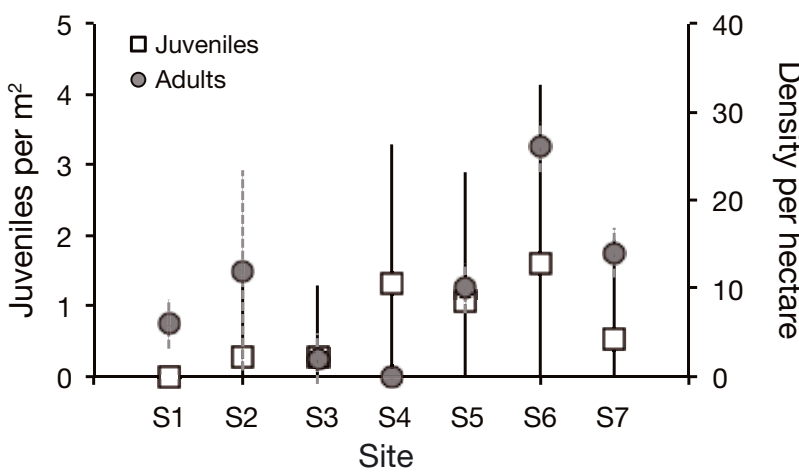

Fig. 6. Distribution patterns of (a) acroporid corals and (b) Acanthaster planci along the Onna coast (Sites S1 to S7). Grey circles and grey dashed lines: mean \pm SD of the abundance of corals and density of adult A. planci; black squares and lines: mean $\pm \mathrm{SD}$ of the numbers of coral recruits and A. planci juveniles

For acroporid corals, previous works had observed year-to-year spatial variability in recruitment patterns from local to regional scales (i.e. between sites within a reef or between reefs in the same region; Fisk \& Harriott 1990, Gleason 1996, Dunstan \& Johnson 1998, Hughes et al. 1999, Glassom et al. 2004, Adjeroud et al. 2007, Nakamura \& Sakai 2010). In contrast, there has been very little research into the distribution of juvenile A. planci (Japan: Yokochi \& Ogura 1987, Fiji: Zann et al. 1987) because of the scarcity of starfish in most years and because of their cryptic habits (Zann et al. 1987).

According to previous recruitment studies of acroporid corals, spatial variability in recruitment patterns may result from complex interactions of differences in larval production, selectivity in settlement, post-settlement mortality, local environmental conditions, topography, and variations in hydrodynamic patterns (Hughes et al. 1999, Nakamura \& Sakai 2010). Moreover, differences in life-history traits between reef species could strongly affect larval dispersal patterns and subsequent recruitment (Pineda et al. 2007). However, our results suggest some degree of similarity in spatial recruitment patterns between acroporid corals and A. planci, despite differences in both their main spawning periods and PLDs.

Most of the GPS drifters released along the Onna coast floated northward along the coast. Their trajectories indicated south-to-north transport along the coast by along-shore currents, related to the geography of the study area (Slinn et al. 2000). Along-shore transport of plankton has been observed in different environments, for example, in the toxic dinoflagellate Alexandrium tamarense (Franks \& Anderson 1992) and for larval dispersal of near-shore species (Aiken et al. 2007). Therefore, similarities and variations in spatial recruitment patterns seen in acroporid corals and $A$. planci are probably due to along-shore currents such that when larvae arrive at the Onna coastal reefs, they are probably carried northward.

Indeed, there were relatively more coral recruits in the northern Onna coast. Acroporid larvae recruited along the northern Onna coast may have originated from the southern part of the study area. Sixteen drifters that were released from the southern part of the Onna coast followed the coastline northeastward and then beached on the northern part of the coast within $3 \mathrm{~d}$, which is the minimum PLD of acroporid corals (Nishikawa \& Sakai 2005, Suzuki et al. 2011).

Why do communities with high coral cover persist in southern Onna in spite of low recruitment in recent years? It could result from the 'storage effect' (Chesson 1983); that is, if strong recruitment occurred in the past, and this cohort survived for a number of potential reproductive periods, this may explain the current large population. However, previous molecular studies demonstrated high genetic connectivity of acroporid corals among different islands along the Ryukyu Archipelago (Nishikawa \& Sakai 2005, Nakajima et al. 2010). Although this study could not determine exactly when the existing acroporid corals were recruited, high genetic connectivity among the islands suggests that populations of acroporid corals in different geographic areas could be maintained by new recruits through larval dispersal processes (Nakajima et al. 2010). In the present study, most drifters that travelled for more than $30 \mathrm{~d}$ passed into the open ocean, where larvae would have little chance to find appropriate settlement locations. However, the drifter data also suggested that larvae could travel as far as 500 to $1300 \mathrm{~km}$ in $30 \mathrm{~d}$. In spite of the low biological and physical settlement potential of acroporid larvae $30 \mathrm{~d}$ after spawning (biologically less than $25 \%$; Nishikawa \& Sakai 2005, and physically as seen in drifter trajecto- 

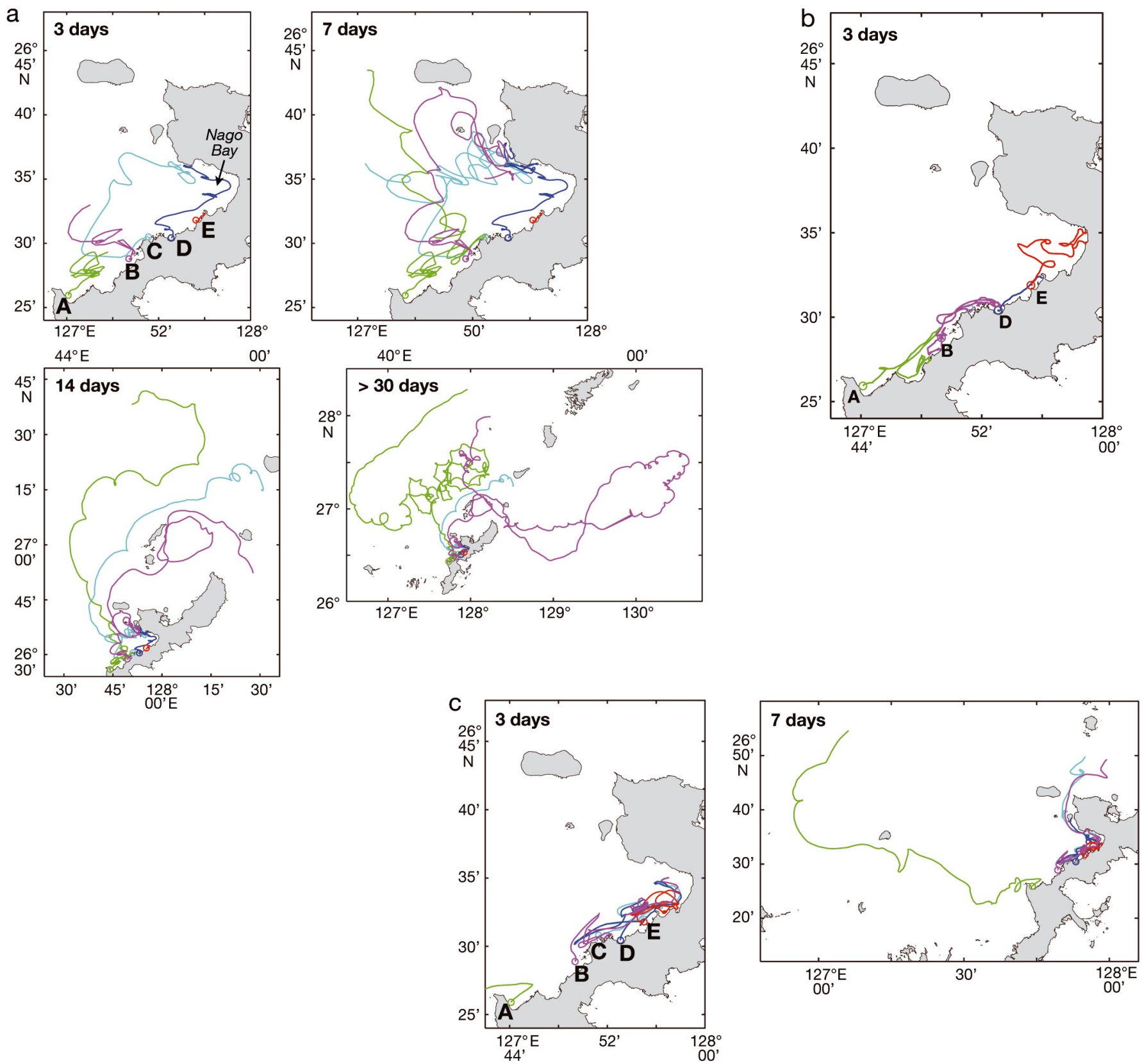

Fig. 7. Trajectories of GPS drifters originating from 5 sites (A to E) along the Onna coast, released on (a) 4 July 2013, (b) 23 July 2013, (c) 23 August 2013, (d) 30 June 2014, and (e) 12 July 2014. Small circles (A to E) and corresponding colored lines show drifter release sites and trajectories (A: green, B: pink, C: aqua, D: blue, E: red)
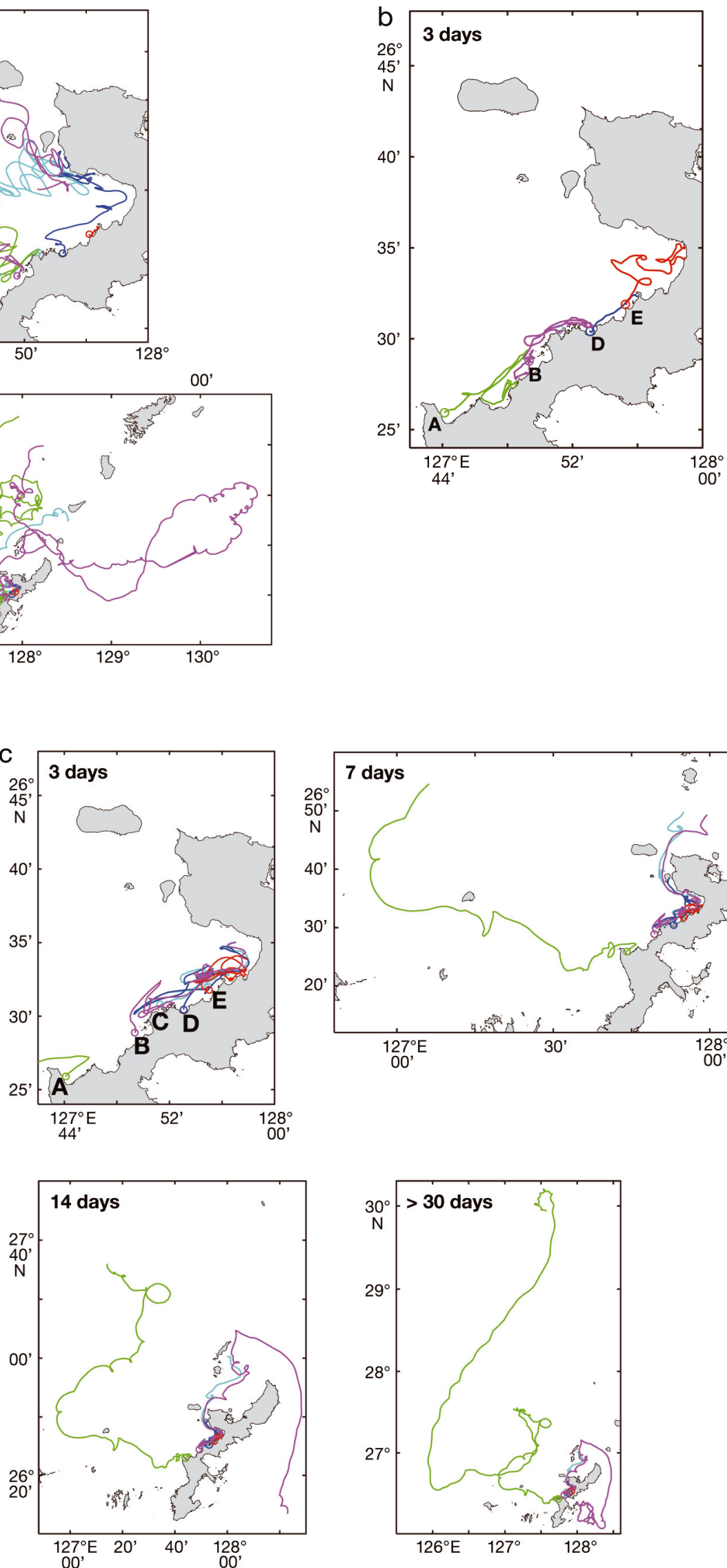

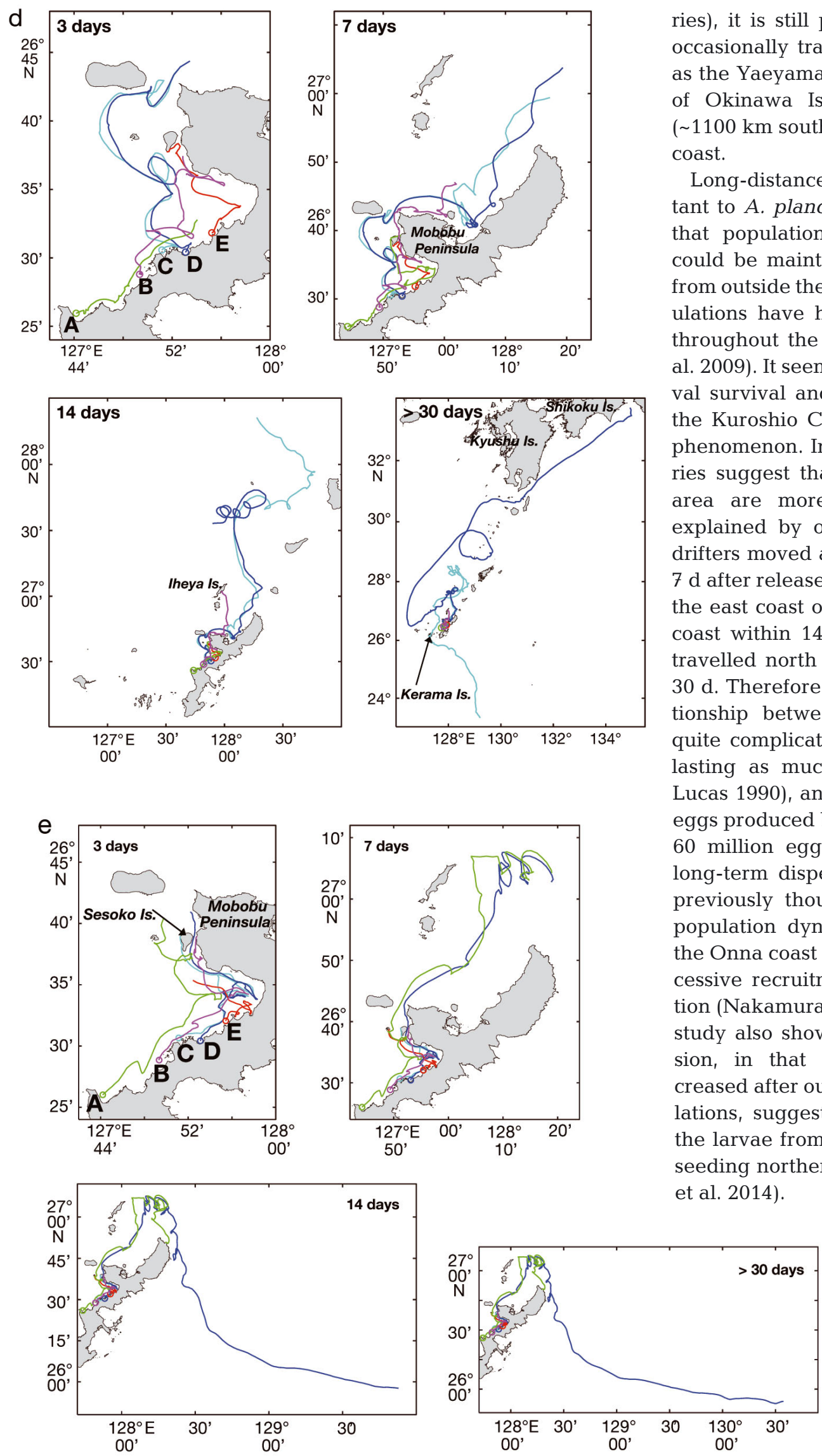

Fig. 7 (continued) ries), it is still possible that larvae could occasionally travel from as far southwest as the Yaeyama area ( 500 km southwest of Okinawa Island) or the Philippines ( 1100 km south of Okinawa) to the Onna coast.

Long-distance dispersal may be important to A. planci, and our results suggest that populations along the Onna coast could be maintained primarily by larvae from outside the Onna area. A. planci populations have high genetic homogeneity throughout the Pacific Ocean (Yasuda et al. 2009). It seems likely that extended larval survival and ocean currents, such as the Kuroshio Current, could explain this phenomenon. In addition, drifter trajectories suggest that surface currents in the area are more complex than can be explained by ocean circulation; most of drifters moved away from the Onna coast $7 \mathrm{~d}$ after release. Some of them traveled to the east coast of Okinawa from the Onna coast within $14 \mathrm{~d}$, and one of them first travelled north and then turned south in $30 \mathrm{~d}$. Therefore, the source and sink relationship between populations could be quite complicated. With the starfish PLD lasting as much as 6 wk (Birkeland \& Lucas 1990), and with the vast number of eggs produced by a single $A$. planci (up to 60 million eggs), the success rate after long-term dispersal may be higher than previously thought. Moreover, historical population dynamics of $A$. planci along the Onna coast suggest that multiple, successive recruitments sustain the population (Nakamura et al. 2014). This previous study also showed a northward progression, in that northern populations increased after outbreaks of southern populations, suggesting that at least some of the larvae from southern populations are seeding northern populations (Nakamura et al. 2014). 
Recruitment patterns could also be affected by epibionts already present on settlement surfaces. Coral larvae prefer to settle and metamorphose on crustose coralline algae (CCA) (Negri et al. 2001, Kitamura et al. 2009, Denis et al. 2014). Moreover, metamorphosis of at least one acroporid species has been induced by a bacterium isolated from the surface of the CCA Hydrolithon onkodes (Negri et al. 2001), which is found at depths of 0.5 to $3 \mathrm{~m}$ (from the reef top in surf) to the reef edge (Womersley 1996). Similarly, in laboratory experiments, metamorphosis of $A$. planci larvae have been induced with bacteria associated with the CCA Lithothamnium pseudosorum, which is found in shallow to deep water (Johnson \& Sutton 1994). Larvae of A. planci have also been observed on substrata encrusted with CCAs, mainly Porolithon spp. (Yokochi \& Ogura 1987, Zann et al. 1987). Thus, metamorphosis and settlement of both acroporid coral and crown-of-thorns starfish appear to be strongly tied to CCAs and the bacteria associated with them. As $H$. onkodes and Porolithon spp. are abundant and widely distributed species in the region (Baba 2000), the similar recruitment patterns of acroporid corals and $A$. planci along the Onna coast may not be greatly affected by the microhabitat for settlement, where substratum selection occurs (Butman 1987).

Early post-settlement mortality has been suggested as critical for shaping recruitment patterns of marine benthos (Hunt \& Scheibling 1997). Post-settlement mortality can be quite high, especially for acroporid corals (Dunstan \& Johnson 1998), and it could diminish, equalize, or accentuate initial spatial differences in recruitment (Dunstan \& Johnson 1998). Causes of mortality could include grazing and predation from fishes and macroinvertebrates (Christiansen et al. 2009, Penin et al. 2010), physical disturbances (e.g. temperature; Nozawa \& Harrison 2007), and spatial competition with fouling organisms and/or algae (Tamai \& Sakai 2013). However, we observed recruitment of corals approximately 1 mo after spawning. Therefore, the effects of post-settlement mortality on coral recruits could also be low, although we could not estimate post-settlement processes accurately in this study. We could not collect continuous field data regarding post-settlement events for $A$. planci because of their scarcity and because of the impossibility of continuous field surveys under difficult ocean conditions. Therefore, we cannot assess the significance of post-settlement mortality on our data, although one previous study of $A$. planci did suggest the importance of initial settlement for spatial population dynamics (Keesing et al. 1996).

\section{CONCLUSIONS}

Corals and Acanthaster planci showed similar patterns of recruitment, due to prevailing along-shore currents on the Onna coast in summer, although their dispersal processes may be quite different due to their early life-history traits (Pineda et al. 2007). Drifter surveys imply a complicated source-sink relationship among populations in this region-especially for A. planci, new recruits of which may come mainly from outside the Onna area. The Kuroshio Current alone cannot explain these patterns. To promote recovery and conservation of coral communities along the Onna coast, it is essential to understand the complex surface circulation in this region in order to locate and eradicate the sink population of $A$. planci in the region. At the same time, potential sources of acroporid coral larvae should be protected. A more complete understanding of larval dispersal is required to identify A. planci populations that are potential sources of larvae for the Onna region.

Acknowledgements. We thank members of the Okinawa Environment Science Center, especially Mr. Tomofumi Nagata and Mr. Eiji Yamakawa, and of the Onna village fisheries cooperative, especially Mr. Yoshimi Higa, Mr. Masami Yamashiro, Mr. Kazuya Hayashi and Mr. Shuichi Mekaru. We also thank Mr. Mori Jinza for helping with estimates of coral cover, and Mr. Shohei Nakada for helping with visualization of drifter trajectories. We thank OIST's technical editor, Dr. Steven D. Aird, for helping us to polish the manuscript. Recruitment data for Acanthaster planci and data regarding $A$. planci densities were provided by Okinawa Prefecture's comprehensive program for management of the crown-of-thorns starfish. This work was partly supported by a Sasakawa Scientific Research Grant from the Japan Science Society and by the comprehensive program for the management of crown-of-thorns starfish of Okinawa Prefecture. We also gratefully acknowledge financial support for this work from Okinawa Institute of Science and Technology Graduate University to the Marine Biophysics Unit.

\section{LITERATURE CITED}

Adjeroud M, Penin L, Carroll A (2007) Spatio-temporal heterogeneity in coral recruitment around Moorea, French Polynesia: implications for population maintenance. J Exp Mar Biol Ecol 341:204-218

Ahrens WH, Cox DJ, Budhwar G (1990) Use of the arcsine and square root transformations for subjectively determined percentage data. Weed Sci 38:452-458

Aiken CM, Navarrete SA, Castillo MI, Castilla JC (2007) Along-shore larval dispersal kernels in a numerical ocean model of the central Chilean coast. Mar Ecol Prog Ser 339:13-24

Baba M (2000) An identification guide of coralline red algae in Japan. Rep Mar Ecol Res Inst 1:1-68

Babcock R, Mundy C (1992) Reproductive biology, spawn- 
ing and field fertilization rates of Acanthaster planci. Mar Freshw Res 43:525-533

> Babcock RC, Bull GD, Harrison PL, Heyward AJ, Oliver JK, Wallace CC, Willis BL (1986) Synchronous spawnings of 105 scleractinian coral species on the Great Barrier Reef. Mar Biol 90:379-394

Babcock RC, Baird AH, Piromvaragorn S, Thomson DP, Willis BL (2003) Identification of scleractinian coral recruits from Indo-Pacific reefs. Zool Stud 42:211-226

Baird AH, Guest JR, Willis BL (2009) Systematic and biogeographical patterns in the reproductive biology of scleractinian corals. Annu Rev Ecol Evol Syst 40:551-571

Birkeland C, Lucas JS (1990) Acanthaster planci: major management problem of coral reefs. CRC Press, Boca Raton, FL

Bruno JF, Selig ER (2007) Regional decline of coral cover in the Indo-Pacific: timing, extent, and subregional comparisons. PLoS ONE 2:e711

Burnham KP, Anderson DR (2002) Model selection and multimodel inference: a practical information-theoretic approach. Springer Science \& Business Media, New York, NY

Butman CA (1987) Larval settlement of soft-sediment invertebrates - the spatial scales of pattern explained by active habitat selection and the emerging role of hydrodynamical processes. Oceanogr Mar Biol Annu Rev 25: 113-165

Chesson P (1983) Coexistence of competitors in a stochastic environment: the storage effect. In: Freedman $\mathrm{H}_{\text {, }}$ Strobeck C (eds) Population biology. Springer, Berlin, p 188-198

> Christiansen NA, Ward S, Harii S, Tibbetts IR (2009) Grazing by a small fish affects the early stages of a post-settlement stony coral. Coral Reefs 28:47-51

> Dayton CM (2003) Information criteria for pairwise comparisons. Psychol Methods 8:61-71

> De'ath G, Moran PJ (1998) Factors affecting the behaviour of crown-of-thorns starfish (Acanthaster planci L.) on the Great Barrier Reef: 2: Feeding preferences. J Exp Mar Biol Ecol 220:107-126

> De'ath G, Fabricius KE, Sweatman H, Puotinen M (2012) The 27-year decline of coral cover on the Great Barrier Reef and its causes. Proc Natl Acad Sci USA 109: 17995-17999

> Denis V, Loubeyres M, Doo SS, de Palmas S, Keshavmurthy S, Hsieh HJ, Chen CA (2014) Can benthic algae mediate larval behavior and settlement of the coral Acropora muricata? Coral Reefs 33:431-440

Dunstan PK, Johnson CR (1998) Spatio-temporal variation in coral recruitment at different scales on Heron Reef, southern Great Barrier Reef. Coral Reefs 17:71-81

Fabricius KE, Okaji K, De'ath G (2010) Three lines of evidence to link outbreaks of the crown-of-thorns seastar Acanthaster planci to the release of larval food limitation. Coral Reefs 29:593-605

> Fisk DA, Harriott VJ (1990) Spatial and temporal variation in coral recruitment on the Great Barrier Reef: implications for dispersal hypotheses. Mar Biol 107:485-490

Fonseca M, Whitfield PE, Kelly NM, Bell SS (2002) Modeling seagrass landscape pattern and associated ecological attributes. Ecol Appl 12:218-237

Franks PJS, Anderson DM (1992) Alongshore transport of a toxic phytoplankton bloom in a buoyancy current: Alexandrium tamarense in the Gulf of Maine. Mar Biol 112:153-164
Glassom D, Zakai D, Chadwick-Furman NE (2004) Coral recruitment: a spatio-temporal analysis along the coastline of Eilat, northern Red Sea. Mar Biol 144:641-651

Gleason MG (1996) Coral recruitment in Moorea, French Polynesia: the importance of patch type and temporal variation. J Exp Mar Biol Ecol 207:79-101

Graham EM, Baird AH, Connolly SR (2008) Survival dynamics of scleractinian coral larvae and implications for dispersal. Coral Reefs 27:529-539

Harrison PL, Wallace CC(1990) Reproduction, dispersal and recruitment of scleractinian corals. In: Dubinsky Z (ed) Ecosystems of the world, Vol 25: Coral reefs. Elsevier, Amsterdam, p 133-207

Hayashibara T, Shimoike K, Kimura T, Hosaka S and others (1993) Patterns of coral spawning at Akajima Island, Okinawa, Japan. Mar Ecol Prog Ser 101:253-262

Hughes TP, Baird AH, Dinsdale EA, Moltschaniwskyj NA, Pratchett MS, Tanner JE, Willis BL (1999) Patterns of recruitment and abundance of corals along the Great Barrier Reef. Nature 397:59-63

Hunt HL, Scheibling RE (1997) Role of early post-settlement mortality in recruitment of benthic marine invertebrates. Mar Ecol Prog Ser 155:269-301

Johnson CR, Sutton DC (1994) Bacteria on the surface of crustose coralline algae induce metamorphosis of the crown-of-thorns starfish Acanthaster planci. Mar Biol 120:305-310

Keesing J, Halford A (1992) Importance of postsettlement processes for the population dynamics of Acanthaster planci (L.). Mar Freshw Res 43:635-651

Keesing JK, Wiedermeyer WL, Okaji K, Halford AR, Hall KC, Cartwright CM (1996) Mortality rates of juvenile starfish Acanthaster planci and Nardoa spp. measured on the Great Barrier Reef, Australia and in Okinawa, Japan. Oceanol Acta 19:441-448

Kitamura M, Schupp PJ, Nakano Y, Uemura D (2009) Luminaolide, a novel metamorphosis-enhancing macrodiolide for scleractinian coral larvae from crustose coralline algae. Tetrahedron Lett 50:6606-6609

> Loya Y, Sakai K, Yamazato K, Nakano Y, Sambali H, van Woesik R (2001) Coral bleaching: the winners and the losers. Ecol Lett 4:122-131

> Millar RB (2009) Comparison of hierarchical Bayesian models for overdispersed count data using DIC and Bayes's factors. Biometrics 65:962-969

Moran PJ, De'ath G (1992) Estimate of the abundance of the crown-of-thorns starfish Acanthaster planci in outbreaking and non-outbreaking populations on reefs within the Great Barrier Reef. Mar Biol 113:509-515

Nakajima Y, Nishikawa A, Iguchi A, Sakai K (2010) Gene flow and genetic diversity of a broadcast-spawning coral in northern peripheral populations. PLoS ONE 5:e11149

- Nakamura M, Sakai K (2010) Spatiotemporal variability in recruitment around Iriomote Island, Ryukyu Archipelago, Japan: implications for dispersal of spawning corals. Mar Biol 157:801-810

Nakamura M, Okaji K, Higa Y, Yamakawa E, Mitarai S (2014) Spatial and temporal population dynamics of the crown-of-thorns starfish, Acanthaster planci, over a 24year period along the central west coast of Okinawa Island, Japan. Mar Biol 161:2521-2530

Negri AP, Webster NS, Hill RT, Heyward AJ (2001) Metamorphosis of broadcast spawning corals in response to bacteria isolated from crustose algae. Mar Ecol Prog Ser 223:121-131 
Nishikawa A, Sakai K (2005) Settlement-competency period of planulae and genetic differentiation of the scleractinian coral Acropora digitifera. Zoolog Sci 22:391-399

Nozawa Y, Harrison P (2007) Effects of elevated temperature on larval settlement and post-settlement survival in scleractinian corals, Acropora solitaryensis and Favites chinensis. Mar Biol 152:1181-1185

Penin L, Michonneau F, Baird AH, Connolly SR, Pratchett MS, Kayal M, Adjeroud M (2010) Early post-settlement mortality and the structure of coral assemblages. Mar Ecol Prog Ser 408:55-64

Pineda J, Hare JA, Sponaugle S (2007) Larval transport and dispersal in the coastal ocean and consequences for population connectivity. Oceanography 20:22-39

R Development Core Team (2014) R: a language and environment for statistical computing. R Foundation for Statistical Computing, Vienna, www.R-project.org

Sakai K, Muzik K, Nakamura S, Nishihira M (1988) A note of resurvey of coral communities and Acanthaster populations around Okinawa Island in 1984. Galaxea 7:41-51

Slinn DN, Allen JS, Holman RA (2000) Alongshore currents over variable beach topography. J Geophys Res 105: 16971-16998

Suzuki G, Arakaki S, Hayashibara T (2011) Rapid in situ settlement following spawning by Acropora corals at Ishigaki, southern Japan. Mar Ecol Prog Ser 421:131-138

Tamai RN, Sakai K (2013) Space competition between coral and algae-effect of two functional groups of algae on juvenile Acropora corals. Galaxea 15:115-122

Editorial responsibility: Charles Birkeland,

Honolulu, Hawaii, USA
Underwood AJ, Fairweather PG (1989) Supply-side ecology and benthic marine assemblages. Trends Ecol Evol 4: $16-20$

Veron JEN (1995) Corals in space and time: the biogeography and evolution of the Scleractinia. Cornell University Press, Ithaca, NY

Womersley HBS (1996) The marine benthic flora of southern Australia. Rhodophyta, Part IIIB. Australian Biological Resources Study, Canberra

Yamaguchi M (1986) Acanthaster planci infestations of reefs and coral assemblages in Japan: a retrospective analysis of control efforts. Coral Reefs 5:23-30

Yasuda N, Nagai S, Hamaguchi M, Okaji K, Gerard K, Nadaoka K (2009) Gene flow of Acanthaster planci (L.) in relation to ocean currents revealed by microsatellite analysis. Mol Ecol 18:1574-1590

- Yasuda N, Ogasawara K, Kajiwara K, Ueno M and others (2010) Latitudinal differentiation in the reproduction patterns of the crown-of-thorns starfish Acanthaster planci through the Ryukyu Island Archipelago. Plank Benth Res 5:156-164

Yokochi H, Ogura M (1987) Spawning period and discovery of juvenile Acanthaster planci (L.) (Echinodermata: Asteroidea) at northwestern Iriomote-Jima, Ryukyu Islands. Bull Mar Sci 41:611-616

Zann L, Brodie J, Berryman C, Naqasima M (1987) Recruitment, ecology, growth and behavior of juvenile Acanthaster planci (L.) (Echinodermata: Asteroidea). Bull Mar Sci 41:561-575

Submitted: May 28, 2015; Accepted: October 21, 2015 Proofs received from author(s): November 13, 2015 